\title{
Support of Road Freight Transport Especially in North-East Part of Schengen Borders
}

\section{Romana Hricová*}

Department of Manufacturing Management, Technical University of Kosice, Bayerova 1, 08001 Prešov, SLOVAK REPUBLIC

*E-mail for correspondence: romana.hricova@tuke.sk

Cell Phone: +421903059919

Received: Jun 29, 2015;

Accepted: Jul 6, 2015;

Published: Aug 06, 2015

Source of Support: Nil

No Conflict of Interest: Declared

\begin{abstract}
Green logistics is very attractive and request the point of view. Many companies try to be "green", but on the other hand they also must be quick, be in right time in the right place and everything with as low costs as possible. So because of it, they use more road freight transport. Nowadays road freight transport is much expanded as transport companies prefer the possibility to operate just-in-time. There are several advantages that give road freight transport the first place. Firstly, the truck can be prepared whenever, no matter what time is chosen. Secondly, the flexibility and no more borders with customs control inside the Schengen Area make freight transport quicker. On the other hand, innovative approaches ask for environmental protection, which becomes one of the most important points of view. If countries support this environmental friendly transport, this would be reflected in the transport prices which should make rail transport more interesting. Using the methodology in the manuscript was divided to three steps. The first step is to identify relevant questions related to border crossing. Next step is to elaborate a list of border problems, and the last step is an analysis of available data.
\end{abstract}

Keywords: logistics, transport, freight, railway, road, Schengen borders, infrastructure

\section{INTRODUCTION}

Modern logistics processes in the field of transport should be introduced and utilized. The Schengen borders are the points of entrance for goods into the European Union and from the European Union. The experience from many border stations is promising and also negative experience can be helpful as it should improve the procedure concerned. The planning of the administrative, customs clearance, communication and information technologies are necessary to modernize in border crossing points. Also, technical capacities must be harmonized with the requirements on those points. Last but not least, the question of good handling with commodities is very important. Certain specialization according to the most frequent commodities must be realized at some border crossing points. Afterwards, there are also some conditions that are given and are impossible to change. On the other hand, sources of delays must be investigated and eliminated. It is important to make the possible solutions as general as possible. Harmonization with European as well as with the national transport policy of each country is very topical problem.

Attention must be paid to infrastructure compatibility of each border crossing pairs at the border crossing points. Here belong technical parameters and conditions. Also for reciprocal trade are very important IT system or communication, safety equipment system as well as electric power system and gauges. But there are also administrative barriers and the different skills. Another very needful thing is knowledge of foreign languages of the drivers.

\section{Common Problems}

As to Central Europe, especially the north-east end of the Schengen area constitutes several cross-boarding points. Poland adjoins two countries that do not belong to the Schengen area (Belarus and Ukraine), the Slovak Republic and Hungary - one country (Ukraine). Technical inspection of rolling stocks, definition of the responsibility fields, the certification procedure of locomotives, different safety equipment system used for the train, as well as different traction system (different electric current tensions between the affected countries), are very topical problems with high priority. And last but not least different interoperability on the railway network and employees' qualification must be solved.

What must be mentioned is that the comparison of the Schengen and non-Schengen borders also shows several problematic parts such as differences in the customs clearance procedures as well as the communication system, which occur principally. Other problems are with cooperation and technical capacities. 


\section{GoALS}

To speed up border crossing inside the Schengen area, new approaches to handling are necessary. These include new IT approaches and process improvements based on the previous analysis of the processes.

Supporting of railway freight transport and its higher competitiveness is possible only if governments solve border-crossing problems and according to this it is necessary to shorten the total time. Handling prearranged time, which should be guaranteed, will be helpful for managing more predictable arrivals.

\section{BORder Situation and ITS Evaluation}

The European Union enlarges what brings larger divergences in terms of transport infrastructure. Especially western and eastern EU parts must be united, mainly in terms of infrastructure. Information technology tools are a good help; these could widely deploy simplicity of administrative procedures, could optimize traffic flows and be useful for cargo tracing and tracking. The White Paper suggests: "The race for sustainable mobility is a global one. Delayed action and timid introduction of new technologies could condemn the EU transport industry to irreversible decline". (The White Paper, 2011) The White Paper also formulates that although many European companies have world leadership in traffic management systems, logistics, infrastructure and manufacturing of transport equipment, the other world regions are still in progress too and so it is necessary to focus on sustainable growth. In that content, it is clear that the transport infrastructure is not equally developed especially in the western and eastern part of the European Union. This asks for increasing pressure to governments on higher investments on freight corridors development. Indispensability is the reduction of administrative and operating costs, limited congestion, to ensure structural change and finally the step by step make railway freight transport more competitive, especially for medium and long distances.

Thanks to the Schengen Area the traditional barriers were reduced, but an administration is higher at the end of the Schengen Area. All the problems moved to that borders, where problems with customs inspections, customs tariffs, administrative and regulatory barriers arose. These barriers must be reduced as well, and efficiency must be maximised. The Global Enabling Trade Report 2014 sets seven pillars of enabling trade. The ETI (Enabling Trade Index) framework

Table 2: Polish border stations

\begin{tabular}{|c|c|c|c|c|c|c|c|}
\hline No. & From & To & $\begin{array}{c}\text { Inter- } \\
\text { operability }\end{array}$ & Customs & $\begin{array}{c}\text { Technical } \\
\text { capacity }\end{array}$ & $\begin{array}{c}\text { Administrative } \\
\text { issues }\end{array}$ & $\begin{array}{c}\text { Average } \\
\text { Waiting time }\end{array}$ \\
\hline 1 & PL -Zwardoń & SK - Skalite & $\mathrm{XX}$ & $\mathrm{X}$ & $\mathrm{XX}$ & $\mathrm{X}$ & $\mathrm{X}$ \\
\hline 2 & $\mathrm{PL}-$ Muszyna & Sk- Plaveč & $\mathrm{XX}$ & $\mathrm{X}$ & $\mathrm{XX}$ & $\mathrm{X}$ & $\mathrm{X}$ \\
\hline $3^{*}$ & $\mathrm{PL}-$ Medyka & $\mathrm{UA}-$ Mostiska & $\mathrm{XXX}$ & $\mathrm{XX}$ & $\mathrm{XXX}$ & $\mathrm{XX}$ & $\mathrm{XXX}$ \\
\hline $4^{*}$ & $\mathrm{PL}-$ Małaszewicze & $\mathrm{BY}-$ Brest & $\mathrm{XXX}$ & $\mathrm{XX}$ & $\mathrm{XXX}$ & $\mathrm{XX}$ & $\mathrm{XXX}$ \\
\hline 5 & $\mathrm{PL}-$ Trakiszki & LT - Mockava & $\mathrm{XXX}$ & $\mathrm{XX}$ & $\mathrm{XXX}$ & $\mathrm{XX}$ & $\mathrm{XXX}$ \\
\hline
\end{tabular}

$\mathrm{PL}=$ Poland, $\mathrm{SK}=$ Slovak republic, $\mathrm{UA}=$ Ukraine, $\mathrm{BY}=$ Belarus, $\mathrm{LT}=$ Lithuania captures various dimensions of enabling trade, breaking them into four overall issue areas, called subindexes:

- The market access which measures the extent and complexity of a country's tariff regime, tariff barriers.

- Border administration assesses the quality, transparency and efficiency of the border administration of a country.

- Infrastructure where transport infrastructure availability and quality of a country, communications infrastructure, associated services, necessity of facilitating the movement of goods within the country and across the border belong.

- Operating environment where the quality of key institutional factors impacting the business of importers and exporters active in a country are measured.

Market access consists of two pillars: The first pillar is Domestic market access (six indicators), second pillar is Foreign market access (two indicators). The Border administration subindex is composed of a single third pillar- Efficiency and transparency of border administration (eleven indicators). The Infrastructure subindex is composed of three pillars: fourth Availability and quality of transport infrastructure (seven indicators), fifth Availability and quality of transport services (six indicators) and sixth Availability and use of ICTs (seven indicators). Finally, Operating environment contains one pillar with the same title and seventeen indicators.

Table 1: Enabling Trade Index of chosen countries

\begin{tabular}{|l|l|l|}
\hline & \multicolumn{2}{|l|}{ Enabling Trade Index 2014 } \\
\hline Country & Rank & Score \\
\hline Singapore & 1 & 5.9 \\
\hline Poland & 45 & 4.3 \\
\hline Hungary & 50 & 4.3 \\
\hline Slovakia & 55 & 4.3 \\
\hline Ukraine & 83 & 3.8 \\
\hline Belarus & n/a & \\
\hline Chad & 138 & 2.5 \\
\hline
\end{tabular}

Note: First and last lines' values in the table 1 are shown only because of comparison

Outcomes of the Global Enabling Trade Report 2014 show that the major problems in rail border procedures in Central Europe should be expected in the trade exchange with non-EU neighbours, especially Ukraine.

\section{Poland}

Border stations, which are interesting for analysis, are shown in Table 2. 
$X=$ minor problem, causes only minor delays

$\mathrm{XX}=$ medium problem, causes often delays

$X X X=$ major problem, causes often and long delays

$\left.{ }^{*}\right)=$ Schengen external border

As table 2 shows, the biggest problems are at the borders Medyka (PL) - Mostiska (UA), Małaszewicze (PL) - Brest (BY) and Trakiszki (PL) - Mockava (LT).

Customs clearance takes place mostly at the border $(75 \%)$, only $25 \%$ is performed in companies. The main problems here are technical capacity, average waiting time and interoperability. There is no one border crossing that is modernized or upgraded, and the government is not planning in the near future any renovations. The other problems as the lack of interoperability of vehicles and personnel with qualification are accepted by neighbouring countries.

Ranking and evaluation of the problems

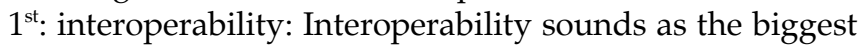
problem as its lack means to stop trains at the border, to replace the locomotive and to change drivers at the borders and also the need to perform actions specific for this infrastructure.

$2^{\text {nd: }}$ border stations and their technical conditions: Especially in Ukrainian border the biggest problems concern track width (gauge) and voltage change. A good solution could be an increase in the use of removable wagon bogies and introduction of wagon bogies (SUW 2000) to daily operation.

$3^{\text {rd }}$ : capacity: The capacity depends on the infrastructure on both sides of the border. The solution could be an application of "nothing to declare" traffic channel. There is also a strong human factor as the traffic organization is fully under the responsibility of a border guards' commander and a day shift manager.

$4^{\text {th }}$ : average waiting time: Many activities must be done while crossing the border. It brings longer waiting time for crossing the state borders.

$5^{\text {th: }}$ customs: These problems are dependent mainly on implementation time of customs clearance.

The way how to reduce waiting times and increase service quality is clear. EU directive 2007/59/WE was transferred into national law in Poland and is currently under way for a transitional period. It is also necessary to improve the organization of train traffic and to increase the use of removable wagon bogies.

\section{Slovak Republic}

Border stations, which are interesting for analysis, are shown in Table 3.

Table 3: Slovakian border station

\begin{tabular}{|c|c|c|c|c|c|c|c|}
\hline No. & From & To & $\begin{array}{c}\text { Inter- } \\
\text { operability }\end{array}$ & Customs & $\begin{array}{c}\text { Technical } \\
\text { capacity }\end{array}$ & $\begin{array}{c}\text { Administrative } \\
\text { issues }\end{array}$ & $\begin{array}{c}\text { Average } \\
\text { Waiting time }\end{array}$ \\
\hline 1 & SK -Štúrovo & HU - Szob & $\mathrm{X}$ & $\mathrm{X}$ & $\mathrm{XX}$ & $\mathrm{X}$ & $\mathrm{XX}$ \\
\hline 2 & SK - Čaňa & HU - Hidasnémeti & $\mathrm{X}$ & $\mathrm{X}$ & $\mathrm{XX}$ & $\mathrm{X}$ & $\mathrm{X}$ \\
\hline $3^{*}$ & SK - Čierna nad Tisou & UA - Chop & $\mathrm{X}$ & $\mathrm{XX}$ & $\mathrm{X}$ & $\mathrm{XX}$ & $\mathrm{XX}$ \\
\hline 4 & SK - Komárno & HU - Komárom & $\mathrm{X}$ & $\mathrm{X}$ & $\mathrm{XX}$ & $\mathrm{X}$ & $\mathrm{XX}$ \\
\hline 5 & SK - Rusovce & HU - Hegyes-halom & $\mathrm{X}$ & $\mathrm{X}$ & $\mathrm{XX}$ & $\mathrm{X}$ & $\mathrm{X}$ \\
\hline
\end{tabular}

$X=$ minor problem, causes only minor delays

$X X=$ medium problem, causes often delays

$\mathrm{XXX}=$ major problem, causes often and long delays

$\left.{ }^{*}\right)=$ Schengen external border

Surprisingly, problems here have medium gravity. The biggest one is to prepare locomotives in order time, which stations managers declare together with insufficient tracks number in border crossing point No.2 (4 available although necessity is at least 6). Also point 3, where shippers crossing Schengen border reported occasional delays of administrative delays and customs inspections from the side of Ukrainian authorities. Important information is, that in most cases the situation can be evaluated as average, and mostly Network statement of ZSR for GVD is kept. Of course, there are several problematic parts that are prepared for improving. It is necessary to make Network Statement of ZSR for GVD (Train time table/diagram) with shorter idle periods of freight trains.

Ranking and evaluation of the problems

$1^{\text {st: }}$ Modernization of rolling stocks.

$2^{\text {nd }}$ : Modernization of infrastructure. $3^{\text {rd: }}$ Modernization of IT (especially IT operational system PIS).

$4^{\text {th }}$ : Better coordination with infrastructure managers on the other side of border.

$5^{\text {th }}$ Faster implementation of ERTMS.

As to the Slovak Republic, modernization of locomotive park is needed (more modern versatile interoperable locomotives) especially for the stations Čaňa (region Košice), Štúrovo, Rusovce, Komárno (region Trnava). Next step would be to make the ordering of locomotives more flexible. Finally, on the Schengen border modernization of IT systems (PIS, customs administrations) and IT-connections among customs administrations in UA and SK is a necessity.

\section{Hungary}

Taking only the north-east part and Schengen border, there is one border station; others are inside the Schengen Area. 
Table 4: Hungarian border station

\begin{tabular}{|c|c|c|c|c|c|c|c|}
\hline No. & From & To & $\begin{array}{c}\text { Inter- } \\
\text { operability }\end{array}$ & Customs & $\begin{array}{c}\text { Technical } \\
\text { capacity }\end{array}$ & $\begin{array}{c}\text { Administrative } \\
\text { issues }\end{array}$ & $\begin{array}{c}\text { Average } \\
\text { waiting time }\end{array}$ \\
\hline 1 & HU - Rajka & SK - Rusovce & $\mathrm{X}$ & No problems occurred & $\mathrm{X}$ & $\mathrm{XX}$ & $\mathrm{X}$ \\
\hline 2 & $\mathrm{HU}-$ Szob & SK - Sturovo & $\mathrm{X}$ & No problems occurred & $\mathrm{X}$ & $\mathrm{XX}$ & $\mathrm{X}$ \\
\hline 3 & HU - Hidasnémeti & SK - Čaňa & $\mathrm{X}$ & No problems occurred & $\mathrm{X}$ & $\mathrm{XX}$ & $\mathrm{X}$ \\
\hline 4 & HU - Komárom & SK - Komárno & $\mathrm{X}$ & No problems occurred & $\mathrm{X}$ & $\mathrm{XX}$ & $\mathrm{X}$ \\
\hline $5^{*}$ & HU - Záhony & UA - Chop & $\mathrm{XXX}$ & $\mathrm{XX}$ & $\mathrm{XX}$ & $\mathrm{XXX}$ & $\mathrm{XXX}$ \\
\hline
\end{tabular}

$X=$ minor problem, causes only minor delays

$\mathrm{XX}=$ medium problem, causes often delays

$\mathrm{XXX}=$ major problem, causes often and long delays

$\left(^{*}\right)=$ Schengen external border

As the Table 4 shows, there is only one weak crossing place (there are no big differences between Slovakian and Hungarian points of view) - Záhony. Actually Záhony is not a real railway junction. Záhony is a compulsory traffic stopping and transshipping place, where general cargo, the bulk goods and the containers are transshipped, because of the rail gauge changing or the wagons' under frame is replaced.

As it was described above, it is impossible to plan the vehicle and duty roster on the Ukraine border because timetable from Ukraine is not able to be held on the freight train traffic.

Ranking and evaluation of the problems

$1^{\text {st: }}$ The throughput in terms of trains especially on the Schengen border is not very high and because of this the freight trains could not hold their timetable, which brings trouble to the inland traffic.

$2^{\text {nd }}$ : Locomotives authorization process is much longer than is required.

$3^{\text {rd }}$ : Traffic congestion on the borders.

$4^{\text {th }}$ : Freight train traffic is not able to hold the timetable from Ukraine, so it is impossible to plan duty and vehicle roster.

Possible ways how to reduce waiting times and to increase service quality are improving cross-border IT technical development; improving communication; developing logistics units. As to the Hungarian-Ukrainian border, very topical are infrastructure renovation, its extension and road access development. Also procedures on the border should be changed (reduce formalities).

\section{CONCLUSION}

Transport operation on the railway infrastructure is subject to the European and national legislative regulations as well as to uniform technological processes and regulations of the railway undertaking. Because of it, problems analysed above are mostly caused by differences between individual states. The most common problems are related with national legislative already - for example, interoperability of the railway networks and administration connected with the customs clearance. Other problems (for example technical capacity and waiting times) are caused by technical problems (for example technical capacity of waiting times).

Bottlenecks, which are observing on the railway networks at the selected borders, must be solved. The rolling stocks and its time consuming technical inspection must be reduced. Communications systems are not always sufficient, and the safety and signalling equipment are also different country by country.
Concerning the staff and vehicles the interoperability is not assured. Problems are mainly in the cooperation at Schengen borders and especially with customs clearance (huge bureaucracy). Because of this the administrative works related to the customs clearance can cause delays and bottlenecks at Schengen borders and must be improved and simplified. There belong border stations Hungary -Ukraine, Slovakia - Ukrainian, Poland - Ukrainian, Belarusian and Lithuanian borders.

Other problems arise with interoperability between freight operators and also problems in the field of the information systems and flows.

In the comparison of Schengen and non-Schengen borders, there are important differences, which must be accepted. For example, there is no customs clearance inside the Schengen Area. But there are several points that must be moderated, for example, communication, cooperation and technical conditions. As the analysis shows, especially Ukrainian border is a weak link because of technical capacities and cooperation.

When responsibilities are redefining, the electrification of the railway lines shall be promoted further. Crossing regulation on borders should be abolished. Infrastructure must be improved as well (electrification, double tracks). Better training and better staff education are also needed.

\section{Expected effects}

There are several effects that should be expected:

- improving of technical inspection of the rolling stock,

- better organization of the responsibilities through the electrification of the tracks,

- $\quad$ the delays can be reduced (first of all at the Ukrainian border),

- the level of the interoperability can be enhanced,

- the quality and the performance of the infrastructure can be improved,

- between the operating parties better communication can be achieved,

- improving cooperation and communication between partners,

- elimination of the interoperability lack and staff problems,

- improvement of the organizational activities and customs clearance services.

\section{REFERENCES}

The Global Enabling Trade Report 2014 (2014), available at http:/ / www3.weforum.org/docs/WEF_GlobalEnablingTr ade_Report_2014.pdf (accessed 12 June 2015).

White paper (2011), Roadmap to a Single European Transport Area - Towards a competitive and resource efficient transport system, available at http:/ / eur-lex.europa.eu/legalcontent/EN/ALL/?uri=CELEX:52011DC0144 (accessed 16 June 2015).

$$
\text { --0-- }
$$

